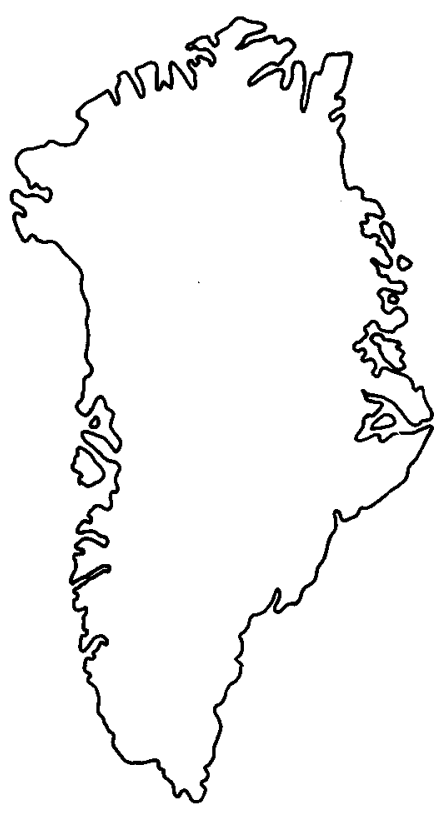

\title{
Gold and platinum group metal mineralisation in the Skaergaard intrusion, southern East Greenland
}

\author{
T. F. D. Nielsen and H. K. Schønwandt
}

\begin{abstract}
A stratabound gold and platinum metal mineralisation has been located in the Tertiary Skaergaard intrusion of the Kangerdlugssuaq area $68^{\circ} \mathrm{N}$ in East Greenland. The mineralisation is located in the upper part of the Middle Zone (MZ) of the layered gabbros and appears continuous over $c .40 \mathrm{~km}^{2}$. The mineralisation is $2-5 \mathrm{~m}$ thick with gold concentrations up to $5.6 \mathrm{~g} / \mathrm{t}, \mathrm{Pd}$ up to $3.5 \mathrm{~g} / \mathrm{t}$ and $\mathrm{Pt}$ up to $1.5 \mathrm{~g} / \mathrm{t}$. Major and trace element distributions indicate that the gold is concentrated in the less mafic layers in the mineralised horizon. It is also concluded that previously reported $\mathrm{TiO}_{2}$ contents of the gabbros and the $\mathrm{TiO}_{2}$ enrichment in the evolving liquids of the intrusion have been underestimated by a factor of $2-3$.
\end{abstract}

T. F. D. N. \& H. K. S., Geological Survey of Greenland, Øster Voldgade 10, DK-1350 Copenhagen K, Denmark.

The Tertiary Skaergaard intrusion in the Kangerdlugssuaq area at $68^{\circ} \mathrm{N}$ on the east coast of Greenland has for five decades served as a type example of layered tholeiitic gabbro intrusions. The intrusion has been extensively studied but a major gold and platinum group metal (PGM) mineralisation has passed unnoticed until 1986 when GGU and Platinova Resources Ltd. of Toronto, Canada, initiated precious metal exploration in the area. The exploration work is now conducted as a joint venture between Platinova Resources Ltd. and Corona Corporation. Much information on the mineralisation is as yet confidential. Here we present some basic geological information and a limited amount of chemical data on the gold-bearing part of the mineralisation. A short account of the gold mineralisation is given earlier in this volume by Nielsen (1990).

\section{The Skaergaard intrusion}

The Skaergaard intrusion (fig. 1; for location see fig. 1 in Nielsen, 1990) is an oval gabbroic body of $55 \mathbf{~ k m}^{2}$ which can be divided into three main units: the Marginal Border Group (MBG), the Upper Border Group (UBG) and the Layered Series (LS). The MBG and the UBG solidified from the contacts inwards while the LS solidified from the bottom and upwards by accumulation and/or growth of minerals at the floor of the magma chamber. On the basis of the presence or absence of olivine as a cumulus phase the exposed Layered Series is divided into a Lower Zone (LZ), Middle Zone (MZ) and Upper Zone (UZ). Ever since the first descriptions by Wager \& Deer (1939) the systematic cryptic variation in mineral compositions up through the LS has been taken as evidence for the crystallisation of the gabbros from a single pulse of tholeiitic magma.

The MBG and the UBG show a mineralogical and geochemical evolution during the solidification similar to that up through the LS. A full description of the intrusion can be found in Wager \& Brown (1968).

\section{The mineralisation}

The gold and PGM mineralisation is regarded as stratabound; it is found in the upper part of the MZ (fig. 1). The mineralisation has been located $8 \mathrm{~km}$ along strike and it is expected to continue below the surface covering an area of approximately $40 \mathrm{~km}^{2}$. The thickness of the mineralised horizon and the gold concentration seems to increase towards the centre of the intrusion. The Platinova Resources Ltd. Annual Report 1988 gives thicknesses in the order of 2-5 $\mathrm{m}$ for the mineralised horizon and concentrations of gold up to $0.17 \mathrm{oz} / \mathrm{t}$ (5.6 ppm), palladium up to $0.11 \mathrm{oz} / \mathrm{t}(3.5 \mathrm{ppm})$ and platinum up to $0.05 \mathrm{oz} / \mathrm{t}(1.5 \mathrm{ppm})$.

Turner (1986), who investigated the distribution and mineralogy of sulphides in the intrusion, suggested that sulphur saturation was reached by the level of the mineralised horizon. This conclusion was based on the observation of complex sulphide droplets in the silicate minerals suggesting the occurrence of an immiscible sulphide liquid.

A petrographic investigation of gabbros from the 


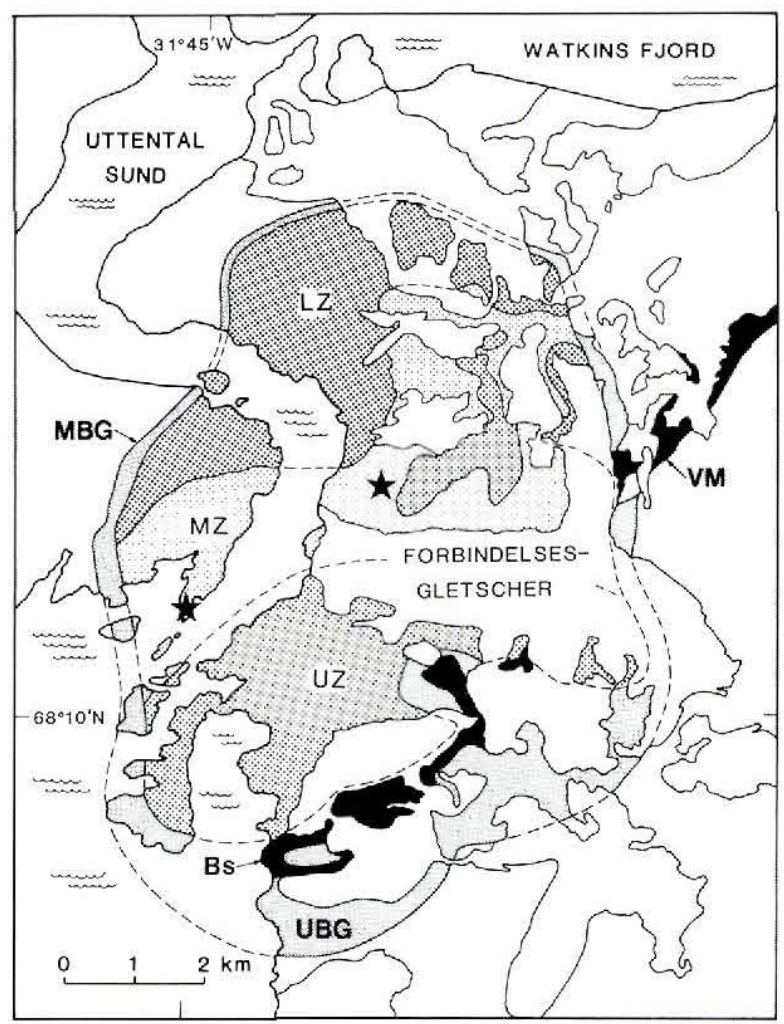

Fig. 1. Simplified geological map of the Skaergaard intrusion. After McBirney (1989). MBG: Marginal Border Group; UBG: Upper Border Group; LZ: Lower Zone, MZ: Middle Zone; UZ: Upper Zone, Bs: Basistoppen sill; VM: Vandfaldsdalen Macro Dyke. According to Platinova Resources Ltd. Annual Report 1988 the mineralised zone is localised in the upper part of the Middle Zone. The stars indicate GGU sample localities.

mineralised horizon suggests a much more complicated origin of the mineralisation. Sulphides and precious metal alloys appear to form separate grains and droplets throughout the less oxide-rich gabbros of the mineralised horizon. These observations appear not to be consistent with a 'simple' immiscible sulphide liquid model.

\section{GGU programme}

In conjunction with universities and research institutions in Denmark and North America as well as Platinova Resources Ltd. GGU has initiated a scientific investigation of the mineralisation. The GGU programme focuses on the following aspects: (1) verification of the reported gold concentrations and (2) correlation between the petrography and geochemistry of the host gabbros and the gold concentrations. Suites of chip and grab samples were collected in 1989 in two profiles across the mineralisation. The chemical results based on the GGU sampling are reported by Nielsen (1989). The main conclusions of the analytical work carried out so far are:

1. The samples collected by GGU from the gold-rich part of the mineralised horizon gave maximum gold values of $4.5 \mathrm{ppm}$ (Table 1) which is in reasonable agreement with the results of the concessionaires.

2. The GGU chip samples gave results within 10 relative per cent of the results reported by the concessionaires.

3. The results indicate that gold is concentrated in the less oxide-rich layers of the gabbro and not in the layers rich in heavy cumulus phases such as ilmenite and magnetite.

4. The analytical results for Pd and Pt from the goldrich part of the mineralised horizon are much lower than the maximum concentrations of $\mathrm{Pd}$ and $\mathrm{Pt}$ reported in Platinova Resources Ltd. Annual Report 1988. This suggests that the gold and PGMs, at least in part, occur in separate parts of the mineralised horizon. The PGM results obtained from the gold-rich part of the mineralised horizon give $\mathrm{Pd} / \mathrm{Pt}$ ratios of $10-15$ and combined $\mathrm{Pd}$ and $\mathrm{Pt}$ concentrations up to $0.6 \mathrm{ppm}$.

\section{Major and trace element compositions of host gabbros}

The mineralised gabbros were analysed for major and trace elements in an attempt to characterise the mineralised horizon geochemically. The major and trace elements and $\mathrm{Au}$ results of selected samples are shown in Table 1.

The major element compositions reveal that the MZ gabbros are very oxide-rich rocks. $\mathrm{TiO}_{2}$ varies from 4.5 to 14 weight $\%$ and total iron expressed as $\mathrm{FeO}$ varies from about 16 to 25 weight $\%$. The $\mathrm{TiO}_{2}$ content is much higher than reported by Wager \& Brown (1968). The same observation was made by McBirney (1989) and it appears that the $\mathrm{TiO}_{2}$ contents of the gabbros and the Skaergaard liquids as defined by Wager \& Brown (1968) have to be revised and increased by a factor of 2 to 3. The much higher levels of $\mathrm{TiO}_{2}$ are in agreement with the liquid compositions for the Skaergaard intrusion suggested by Brooks \& Nielsen $(1978,1989)$ on the basis of the composition of contemporaneous tholeiitic dyke rocks.

In the mineralised horizon a negative correlation is observed between $\mathrm{Au}$ and $\mathrm{FeO}, \mathrm{TiO}_{2}$ and $\mathrm{V}$, whereas the correlation with some of the incompatible elements such as $\mathrm{Rb}, \mathrm{Nb}$ and $\mathrm{Y}$ is positive. This is in accordance with the observed concentration of gold in the less oxide-rich rocks of the mineralised horizon (Nielsen, 1989). 
Table 1. Selected Middle Zone gabbro compositions of the Skaergaard intrusion

\begin{tabular}{|c|c|c|c|c|}
\hline & 1 & 2 & 3 & 4 \\
\hline $\mathrm{SiO}_{2}$ & 45.23 & 41.30 & 35.77 & 42.79 \\
\hline $\mathrm{TiO}_{2}$ & 5.88 & 8.47 & 12.31 & 6.79 \\
\hline $\mathrm{Al}_{2} \mathrm{O}_{3}$ & 8.62 & 8.31 & 7.79 & 11.53 \\
\hline $\mathrm{Fe}_{2} \mathrm{O}_{3}$ & 2.98 & 4.98 & 5.74 & - \\
\hline $\mathrm{FeO}$ & 15.87 & 17.28 & 20.19 & 20.00 \\
\hline $\mathrm{MnO}$ & 0.29 & 0.29 & 0.29 & 0.26 \\
\hline MgO & 7.94 & 7.34 & 6.58 & 6.24 \\
\hline $\mathrm{CaO}$ & 10.67 & 9.74 & 8.54 & 9.87 \\
\hline $\mathrm{Na}_{2} \mathrm{O}$ & 1.59 & 1.55 & 1.46 & 2.23 \\
\hline $\mathrm{K}_{2} \mathrm{O}$ & 0.16 & 0.15 & 0.09 & 0.21 \\
\hline $\mathrm{P}_{2} \mathrm{O}_{5}$ & 0.08 & 0.06 & 0.05 & 0.08 \\
\hline \multirow{2}{*}{ 1.o.i. } & 0.79 & -0.91 & 0.66 & - \\
\hline & 100.09 & 100.38 & 99.46 & 100.00 \\
\hline Mg no. & 0.464 & 0.406 & 0.344 & - \\
\hline \multicolumn{5}{|c|}{ Reconnaissance trace elements (XRF, ppm) } \\
\hline $\mathrm{V}$ & 710 & 1241 & 2135 & - \\
\hline $\mathrm{Cr}$ & n.d. & 2 & 13 & - \\
\hline $\mathrm{Ni}$ & 35 & 36 & 26 & - \\
\hline $\mathrm{Cu}$ & 147 & 80 & 384 & - \\
\hline $\mathrm{Zn}$ & 131 & 150 & 156 & - \\
\hline $\mathbf{R b}$ & 7 & 1 & n.d. & - \\
\hline $\mathrm{Sr}$ & 132 & 118 & 86 & - \\
\hline $\mathbf{Y}$ & 17 & 10 & n.d. & - \\
\hline $\mathrm{Zr}$ & 88 & 92 & 64 & - \\
\hline $\mathrm{Nb}$ & 8 & 5 & n.d. & - \\
\hline $\mathrm{La}$ & 11 & 8 & 2 & - \\
\hline $\mathrm{Ce}$ & 64 & 89 & 111 & - \\
\hline $\mathrm{Au}^{*}$ & 4.53 & 0.38 & - & - \\
\hline
\end{tabular}

n.d.: not detected; - : not determined.

1.o.i.: loss on ignition.

* Neutron activation analysis.

1. Melanocratic gabbro, GGU 348816, Kræmer $\varnothing$.

2. Mafic oxide-rich gabbro, GGU 348811, Kræmer $\emptyset$.

3. Oxide-rich mafic gabbro, GGU 348821, Kræmer $\varnothing$.

4. Average Middle Zone gabbro (McBirney, 1989, Table 5, All MZ).

\section{Conclusions}

These petrographic and geochemical results suggest that concentration processes other than the settling of an immiscible sulphide liquid during the crystallisation of the basaltic liquid were involved in the formation of the mineralised horizon. The high distribution coefficients for precious metals in sulphide liquids would probably not result in a separation of the sulphides and precious metal alloys in separate grains. It is at present unknown whether the mineralisation is caused by sulphide liquid immiscibility, by a late magmatic concentration of sulphur and precious metals in the intercumulus liquid, to a post-magmatic process or to combinations of these processes.

Acknowledgements. Platinova Resources Ltd. is thanked for hospitality and help during inspection visits to the Skaergaard intrusion, and L. M. Larsen is thanked for critical comments.

\section{References}

Brooks, C. K. \& Nielsen, T. F. D. 1978: Early stages in the differentiation in the Skaergaard magma as revealed by a closely related suite of dike rocks. Lithos 11, 1-14.

Brooks, C. K. \& Nielsen, T. F. D. 1990: The differentiation of the Skaergaard intrusion. A discussion of Hunter and Sparks (Contrib Mineral Petrol 95: 451-461). Contrib. Mineral. Petrol. 104, 244-247.

McBirney, A. R. 1989: The Skaergaard Layered Series: 1. Structure and average compositions. J. Petrol. 30, 363-397.

Nielsen, T. F. D. 1989: Gold mineralisation in the Skaergaard intrusion. Open File Ser. Grønlands geol. Unders. 89/7, 14 pp.

Nielsen, T. F. D. 1990: A gold mine in East Greenland? Rapp. Gronlands geol. Unders. 148, 40-43 (this volume).

Turner, P. A. 1986: Sulphide mineralogy and the behavior of S and certain transition elements in the Skaergaard intrusion, East Greenland. M.Sc. thesis, Dartmouth College, New York, U.S.A.

Wager, L. R. \& Deer, W. A. 1939: Geological investigations in East Greenland. Part III. The petrology of the Skaergaard intrusion, Kangerdlugssuaq, East Greenland. Meddr Grønland 105(4), $352 \mathrm{pp}$.

Wager, L. R. \& Brown, G. M. 1968: Layered igneous rocks, 588 pp. Edinburgh \& London: Oliver \& Boyd. 